\title{
Temporal variations of larval digenean assemblages parasitizing Heleobia parchappii (Mollusca: Cochliopidae) in two shallow lakes from the Buenos Aires province, Argentina
}

\author{
Matías J. Merlo (D), Manuela Parietti (1) \& Jorge A. Ełchegoin (1)
}

Laboratorio de Parasitología, Instituto de Investigaciones en Producción Sanidad y Ambiente (IIPROSAM), Facultad de Ciencias Exactas y Naturales, Universidad Nacional de Mar del Plata - Consejo Nacional de Investigaciones Científicas y Técnicas (CONICET), Juan B. Justo 2550, (7600) Mar del Plata, Argentina. (mjmerlo@mdp.edu.ar)

ABSTRACT. The larval digenean assemblages in snail hosts are influenced by biotic and abiotic factors and by environmental disturbances due to human activities. Given their susceptibility to different types of impact, they can be useful tools for the study of temporal variations in parasite communities. The study of temporal dynamics in prevalence and species richness of larval digenean assemblages of Heleobia parchappii (D'Orbigny, 1835), in two Pampean lakes, provides a good opportunity to test the supposition that seasonal variations in digenean assemblages are determined by a series of biotic and abiotic factors that operate interdependently. To analyze the temporal variations, and to evaluate how local factors influence these digenean assemblages in Los Padres and La Brava lakes (Buenos Aires province, Argentina), 2,400 specimens of $H$. parchappii were collected seasonally, during one year. The digenean assemblages in Los Padres and La Brava lakes were composed of 13 and 12 species respectively. These larval digenean assemblages showed similarities in the number and in the seasonal frequency of occurrence of species (eight of which were present in both lakes). However, despite these similarities, the assemblages showed different temporal dynamics in La Brava and Los Padres lakes and, also, different correlations with the abiotic and biotic factors analyzed during this study (temperature, high of the water column and snail relative abundance). Temporal dynamics in prevalence and species richness of larval digenean assemblages of $H$. parchappii in both lakes seems to be influenced by a series of factors (diversity and abundance of definitive hosts, intermediate and definitive host location, snail relative abundance and anthropogenic disturbances). Our results highlight the importance of analyzing the role and interaction of local factors, especially in studies dealing with spatiotemporal fluctuations or with distance decay of similarities in species richness of parasite assemblages.

KEYWORDS. Molluscan host, seasonal dynamics, environmental factors, anthropogenic disturbances.

Among the parasites, the digeneans (Phylum Platyhelminthes, Class Trematoda, Subclass Digenea) have proven to be good study models for the investigation of temporal fluctuations in host-parasite systems (GÉRARD, 2001; Yurlova et al., 2006; HERRMANn \& SorEnSEN, 2009; Studer \& Poulin, 2012; Parietti et al., 2013, among others). To complete their life cycles, digeneans usually requires three hosts: a definitive host (generally a vertebrate), a first intermediate host (always a mollusc) and a second intermediate host that can be invertebrate or vertebrate (e.g.: molluscs, annelids, crustaceans, fishes, amphibians). In the mollusc first intermediate host, the parasites develop free-living infective stages (cercariae). Once released into environment, the cercaria infects the second intermediate host and develop other larval stage (metacercaria). Finally, the second intermediate hosts are eaten by the definitive hosts within which metacercariae reach the adult stage (Yamaguti, 1975; GinetsinsKaya, 1988; GalaKtionov \& DobrovolsKiJ, 2003).

In parasites with complex life cycles, like digeneans, the environmental factors can determine the selection of habitat by the hosts and, therefore, the spatial coincidence of all the hosts required to complete these life cycles (COMBES, 2001). The environmental factors can also have a strong influence on the development and mobility of digenean free-living stages (miracidia and cercariae). These larval stages have short life spans and limited dispersal and, once released to the environment, they should quickly contact and infect the next host of the life cycle to survive (EsCH \& FERNÁNDEZ, 1994; GALAKTIONOV \& DoBRovolsKIJ, 2003; SuKHDEO \& SuKHDEO, 2004). The environmental factors, such as temperature, light, salinity, $\mathrm{pH}$, ultraviolet radiation, can interfere with this process, limiting or preventing the presence of a digenean species in a particular ecosystem (Pietrock \& Marcogliese, 2003).

The larval digenean assemblages in snail hosts are also influenced, positively or negatively, by environmental disturbances due to human activities (KURIS \& LAFFERTY, 1994; KeAs \& BlanKeSPOOR, 1997; HuSPENI \& LAFFERTY, 2004; Blanar et al., 2009; Di Giorgio et al., 2016). Human pollution may affect digenean survival and ability to infect snails (Pietrock \& MArcogliese, 2003), and an increase 
in human activities in a given ecosystem could reduce the permanence of birds in the area, interfering with the encounter between the upstream hosts (birds) and the downstream hosts (snails) of the digenean life cycles (LAFFERTY, 1997; Etchegoin \& Merlo, 2011; Etchegorn et al., 2012).

In the Southeastern of Buenos Aires Province (Pampean region, Argentina), La Brava and Los Padres are the most important shallow lakes of the area. These lakes contribute with several ecosystem services (e.g. nutrient cycling, water and climate regulation, recreation) (RoMANELLI et al., 2011), and play an important role in the conservation of biodiversity by providing feeding and reproduction areas to resident and transient bird species (JosENS et al., 2009). In the latest years, these lakes have been impacted by human activities and they undergo environmental stress due to the increase of nutrient loading from agriculture activities and urbanization (RomANELLI et al., 2011). On the other hand, recreational activities along their shores during weekends and holidays also contribute to the environmental stress in these lakes.

The snail Heleobia parchappii (d'Orbigny, 1835) (Cochliopidae) is a common and abundant component of freshwater environments in northern and central Argentina (Ruml et al., 2008) and, in the Southeastern of Buenos Aires Province serves as host to, at least, 25 digenean species. This molluscan species is also abundant in La Brava and Los Padres lakes, and is associated with the littoral vegetation [dominated by the giant bulrush Schoenoplectus californicus (C.A.Mey.) Soják].

Taking into account that studies regarding temporal variations in parasite/invertebrate relationships are still scanty in South America, the presence of a molluscan host with species-rich digenean assemblages in two lakes with similar geographical location and topography, provides a good opportunity to test the supposition that seasonal variation in digenean assemblages are determined by a series of biotic and abiotic factors that operate interdependently. For that reason, the main goals of this study were: a) to analyze the temporal variation of the larval digeneans parasitizing $H$. parchappii in La Brava and Los Padres lakes and, b) to evaluate how local factors influence these digenean assemblages in both lakes.

\section{MATERIAL AND METHODS}

Sampling sites. The selected sampling sites were two intermountain shallow lakes located in the Southeastern Pampa plain, Argentina: La Brava ( $\left.37^{\circ} 52^{\prime} \mathrm{S}, 57^{\circ} 58^{\prime} \mathrm{W}\right)$, and Los Padres (37 $56^{\prime}$ S, $57^{\circ} 44^{\prime} \mathrm{W}$ ) (Fig. 1). These lakes are characterized by different surface areas and by different values of maximum depth $\left(4 \mathrm{~km}^{2} ; 4 \mathrm{~m}\right.$, and $2.16 \mathrm{~km}^{2} ; 2.1 \mathrm{~m}$, respectively) and by being naturally euthropic (ROMANELLI et al., 2013).

Sampling procedures. Snails were collected from winter 2010 to autumn 2011 in the two lakes. One sampling trip per season was made and five replicates per sampling trip were taken along a $200 \mathrm{~m}$ transect parallel to the coastline. Specimens of $H$. parchappii located among the submerged vegetation and on the substratum were collected with the aid of sieves $(0.5 \mathrm{~mm})$ and placed into plastic cups filled with water from the lakes for transportation. The water temperature was measured using a Digital Multi-Thermometer (range $-50{ }^{\circ} \mathrm{C}$ to $150^{\circ} \mathrm{C}$ ), and a metric aluminum rod was used to measure the height of the water column. The relative abundance of $H$. parchappii was estimated by reference to standardized search effort (number of snails caught per hour), and conducted by the same person to avoid sampling bias. This method for quantifying abundance was adopted due to the turbidity of the lake, which made it impossible to either view the substratum or collect all of the snails in a given area (MARTín et al., 2001).

The sample size was calculated according to the methodology developed in MerLo et al. (2010), and a total of 60 randomly selected snails (for each replicate) were isolated individually in $45 \mathrm{ml}$ plastic cups and maintained under a 12-12 light-dark photoperiod for $48 \mathrm{~h}$ to stimulate shedding of larval digenean (cercariae). Subsequently, snails were measured under a stereoscopic microscope with an ocular micrometer (precision $0.05 \mathrm{~mm}$ ). Total shell length (the distance from the apex to the anterior margin of the aperture) was used as an estimate of size. Finally, all snails were dissected under a stereomicroscope in order to detect the presence of sporocysts, rediae and developing cercariae (pre-patent infections) (CURTIS \& HUBBARD, 1990), which were identified according to SzIDAT (1956), Yamaguti (1975), MARTORELLI (1986, 1989, 1990), Martorelli \& EtCHEGOIN (1996), EtCHEGOIN \& MARTORELli (1998) and Merlo et al. (2014).

Data analysis. In order to analyze the seasonal variation in species composition of the larval digenean assemblage, and to estimate the contribution of the different groups of vertebrates to the life cycles of digeneans parasitizing $H$. parchappii, we calculated: 1 ) the seasonal frequency of occurrence of these species; 2) the number and combinations of multiple infestations, and 3) the percentage of digenean species that use birds, mammals, fish, amphibians or reptiles as definitive hosts. Given that not all the life cycles

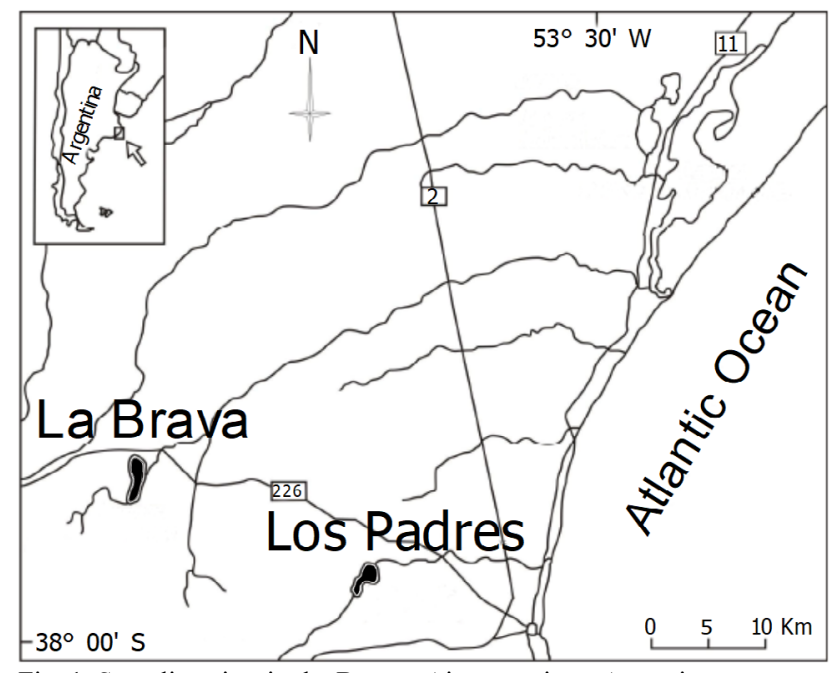

Fig. 1. Sampling sites in the Buenos Aires province, Argentina. 
of the digeneans that parasitize $H$. parchappii in the two lakes are still known, the larval stages were identified and assigned to a family of digeneans, according to YAMAGUTI (1975). For that reason, some families include more than one group of vertebrates as definitive hosts.

To analyze and to compare the temporal dynamics of larval digenean assemblages of $H$. parchappii for the two lakes, the following indices were calculated: a) Overall prevalence $=($ the number of parasitized snails/the number of collected snails) $\times 100$ (LAFFERTY et al., 1994), b) Species richness (S), the total number of species in a sample (Ludwig \& Reynolds, 1988; Magurran, 1988), and c) ShannonWiener species diversity index: $\mathrm{H}^{\prime}=-\Sigma(\mathrm{pi} \times \ln \mathrm{pi})$ (MAGURRAN, 1988).

An ANCOVA test was used to analyze the temporal dynamics of the overall prevalence in each lake, using total length of $H$. parchappii as covariable. The seasonal comparison of species richness was made using an ANOVA test. Tukey tests were performed for post-hoc comparisons (ZAR, 2009). Homogeneity of variances and normality were confirmed prior to all analyses.

Finally, to establish possible relationships between the seasonal overall prevalence and abiotic factors (temperature and high of water column), as well as between snail relative abundance and prevalence, Pearson correlation index was applied analyzes were performed in all cases.

\section{RESULTS}

In Los Padres lake, 1,200 specimens of $H$. parchappii were examined, and 13 digenean species, belonging to nine families, were observed (Tab. I). No multiple infestations were recorded throughout the study. From the 13 digenean species, 58.3\% use birds and mammals, 16.6\% use birds, mammals and fish, $16.3 \%$ use fish, and $8.3 \%$ use fish, reptiles and amphibians as definitive hosts (Tab. I). Finally, a total of seven species were observed in all seasons. The remaining species were recorded in one, two or three seasons (two species in all cases).

The ANCOVA test of the seasonal prevalence, revealed a significant snail's size effect $\left(\mathrm{F}_{1,15}=4.81 ; \mathrm{p}<0.05\right)$. No significant differences between the seasons were found after correction carried out from the effect due to the snail's size $\left(\mathrm{F}_{3 ; 15}=1.93 ; \mathrm{p}=0.17\right)$ (Fig. 2).

The species richness revealed significant differences between the seasons (ANOVA, $\mathrm{F}_{3 ; 16}=10.89$; $\mathrm{p}<0.05$ ). Subsequent comparison of the species richness, by pairs, revealed that summer was the season with the highest number of species (10.4), being significantly different from the three remaining stations $(\mathrm{p}<0.05$, for all cases). No significant differences between winter, spring and autumn were observed ( $\mathrm{p}>0.05$, for all cases) (Fig. 3).

Shannon-Wiener species diversity index reached the maximum value in summer $\left(\mathrm{H}^{\prime}=3.35\right)$ and the lowest value was observed in winter $\left(\mathrm{H}^{\prime}=2.20\right)$. Spring and autumn showed intermediate but similar values $\left(\mathrm{H}^{\prime}=2.65\right.$ and $\mathrm{H}^{\prime}=$ 2.75, respectively).

Pearson's correlation index did not reveal significant relationships between prevalence and the abiotic and biotic factors analyzed (temperature vs prevalence: $\mathrm{r}^{2}=0.17 ; \mathrm{p}=0.07$, height of the water column vs prevalence: $\mathrm{r}^{2}=0.002 ; \mathrm{p}=0.84$, and relative abundance of $H$. parchappii vs prevalence: $\left.\mathrm{r}^{2}=0.02 ; \mathrm{p}=0.51\right)$.

Tab. I. List of species or morphological types of larval digeneans parasitizing Heleobia parchappii (d'Orbigny, 1835) in La Brava (LB) and Los Padres (LP) lakes, Buenos Aires, Argentina. References: 1, Etchegoin \& Martorelli (1998); 2, MARTORelli \& EtchegOIN (1996); 3, EtcheGOIN (1997); 4, Present study; 5, Martorelli (1990); 6, Martorelli (1986); 7, Szidat (1956); 8, Martorelli (1989).

\begin{tabular}{|c|c|c|c|}
\hline Family & Species & Lake & Definitive host \\
\hline Notocotylidae & Notocotylidae sp. $1^{1}$ & LP, LB & Birds and mammals \\
\hline \multirow{4}{*}{ Heterophyidae } & Pleurolophocercaria $\mathrm{VI}^{2}$ & LP & \multirow{4}{*}{ Birds and mammals } \\
\hline & Pleurolophocercaria $\mathrm{II}^{3}$ & LP, LB & \\
\hline & Cercaria Heterophyidae sp. $8^{4}$ & LP, LB & \\
\hline & Cercaria Heterophyidae sp. $9^{4}$ & LB & \\
\hline \multirow{2}{*}{ Echinostomatidae } & Echinocercaria sp. $1^{3}$ & LP & \multirow{2}{*}{ Birds, mammals and fishes } \\
\hline & Cercaria heleobicola IV 5 & LP & \\
\hline \multirow{2}{*}{ Microphallidae } & Microphallus simillimus ${ }^{3}$ & LP, LB & \multirow{2}{*}{ Birds and mammals } \\
\hline & Microphallus szidati $i^{3,6}$ & LP, LB & \\
\hline Psilostomatidae & $\begin{array}{l}\text { Cercaria aff. Psilochasmus } \\
\text { oxyurus }^{1} \text { (Creplin, 1835) }\end{array}$ & LP, LB & Birds and mammals \\
\hline Haploporidae & Cercaria Haploporidae sp. $3^{4}$ & LP, LB & Fishes \\
\hline \multirow{2}{*}{ Hemiuridae } & Cercaria Hemiuridae sp. $1^{4}$ & LP & \multirow{2}{*}{ Fishes } \\
\hline & Genarchella genarchella ${ }^{7 ; 8}$ & LB & \\
\hline Acanthostomidae & Cercaria Acanthostomidae sp. $1^{4}$ & LP, LB & Fishes, amphibians and reptiles \\
\hline Schistosomatidae & Furcocercaria sp. $2^{4}$ & LB & Birds and mammals \\
\hline Lecithodendriidae & Cercaria Lecithodendriidae sp. $1^{4}$ & LB & Birds and mammals \\
\hline Plagiorchiidae & Xiphidiocercaria sp. $3^{4}$ & LP & Reptiles, birds and mammals \\
\hline
\end{tabular}




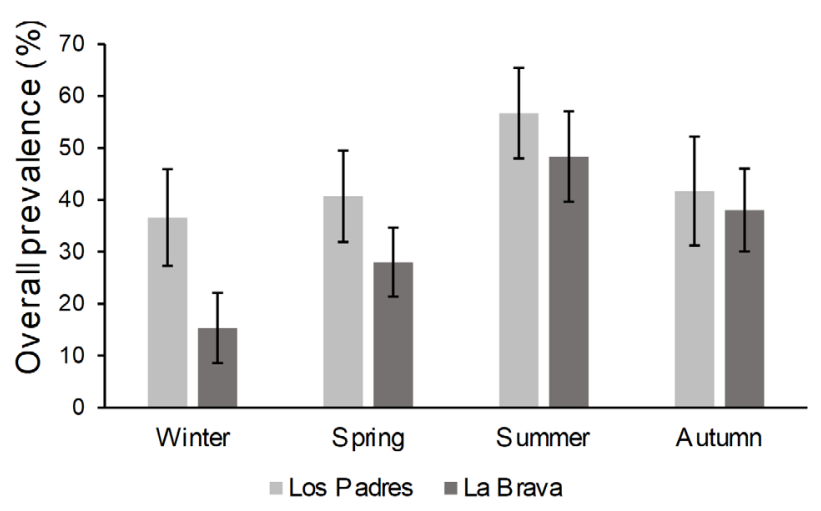

Fig. 2. Seasonal variation in the Overall prevalence (mean \pm S.D) of larval digeneans parasitizing Heleobia parchappii (D’Orbigny, 1835) in Los Padres and La Brava lakes, Buenos Aires province, Argentina.

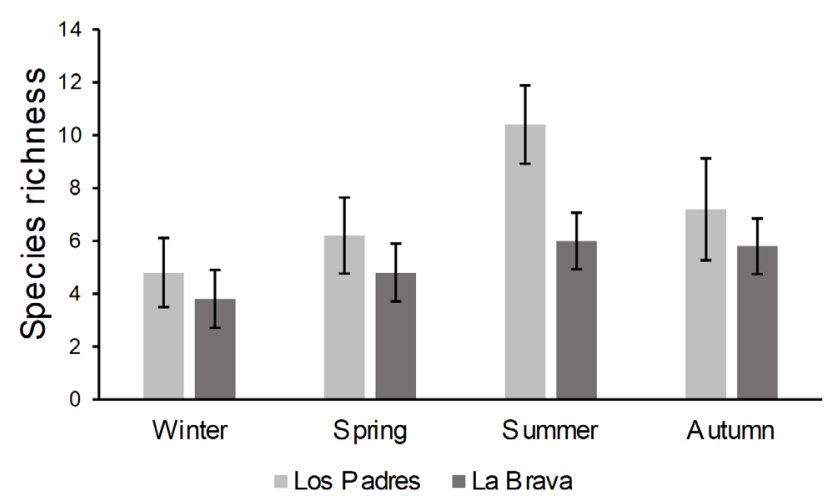

Fig. 3. Seasonal variation in Species richness (mean \pm S.D) of larval digeneans parasitizing Heleobia parchappii (D’Orbigny, 1835) in Los Padres and La Brava lakes, Buenos Aires province, Argentina.

In La Brava lake, 1,200 specimens of H. parchappii were examined, and 12 digenean species, belonging to nine families, were observed (Tab. I). A total of nine double infestations were observed throughout the study, representing $2.3 \%$ of the total infestations registered in the four seasons. Only three species combinations were observed: Microphallus szidati / Genarchella genarchella, Microphallus simillimus / Cercaria Acanthostomidae sp. 1, and Cercaria Heterophyidae sp. 8 / Echinocercaria sp. 1. The first combination was registered seven times (three during the summer and four during the autumn), the second and third combinations were registered only once (during the winter and during the spring, respectively). From the 12 digenean species, $66.7 \%$ use birds and mammals, $16.6 \%$ use fish, and $8.3 \%$ use fish, reptiles and amphibians as definitive hosts (Tab. I). A total of eight species were observed in all seasons. The remaining species were recorded in one or two seasons (two species in both cases).

The ANCOVA test of the seasonal prevalence, did not revealed a significant snail's size effect $\left(\mathrm{F}_{1,15}=0.05 ; \mathrm{p}=0.83\right)$. Likewise, ANCOVA test revealed the existence of temporal heterogeneity in the prevalence $\left(F_{3 ; 15}=9.99 ; p<0.05\right)$. Tukey's test detected significant differences between: summer-spring, summer-winter and autumn-winter $(\mathrm{p}<0.05$, for all cases) (Fig. 2).
The species richness did not show significant differences between the seasons (ANOVA, $\mathrm{F}_{3 ; 16}=2.14$; $\mathrm{p}=0.13$ ) (Fig. 3). The Shannon-Wiener species diversity index also showed similar values for all seasons $\left(\mathrm{H}^{\prime}{ }_{\text {winter }}=1.96\right.$, $\mathrm{H}_{\text {spring }}^{\prime}=2.23, \mathrm{H}_{\text {summer }}^{\prime}=2.42$ and $\mathrm{H}^{\prime}{ }_{\text {autumn }}=2.34$ ).

Pearson's correlation index did not reveal significant relationships between prevalence and the abiotic factors analyzed (temperature vs prevalence: $\mathrm{r}^{2}=0.15 ; \mathrm{p}=0.08$; water vs prevalence: $\mathrm{r}^{2}=-0.04 ; \mathrm{p}=0.37$ ). On the contrary, the relative abundance of $H$. parchappii showed a positive correlation with the total prevalence $\left(r^{2}=0.41 ; p<0.01\right)$.

\section{DISCUSSION}

The temporal variation in prevalence and species richness is one of the characteristic features of the larval digenean assemblages in the first intermediate host (ESCH \& FernáNDEZ, 1994; EsCH et al., 2001; KuBE et al., 2002). The factors that has been linked to this variability include the environmental conditions (water and air temperature, height of the water column, salinity, etc.), the biology of the intermediate hosts (habitat use, density, duration of the host life cycle, etc.), the biology of definitive host (diversity, abundance, behavior, etc.), and interspecific interactions between larval digeneans (CURTIS \& HURD, 1983; FERNÁNDEZ \& EsCH, 1991; SOUSA, 1993; LAFFERTY et al., 1994; JOKELA \& Lively, 1995; Granovitch et al., 2000; Pietrock \& Marcogliese, 2003; Fingerut et al., 2003; Poulin, 2006; Poulin \& Mouritsen, 2006; Byers et al., 2008; FaLTÝnKová et al., 2008, among others).

The larval digenean assemblages of $H$. parchappii, in Los Padres and in La Brava lakes, showed similarities in the number and in the seasonal frequency of occurrence of species. The diversity of these assemblages also showed a similar pattern, reaching a peak during the summer. In addition, from the total species of larval digeneans recorded during this study, eight were present in both lakes. Because the lakes are not connected to each other, the presence of the shared species in Los Padres and La Brava lakes could be due to the fact that the two lakes serve as habitats for the definitive hosts (mainly birds) of these parasites. In this regard, JosEns et al. (2009) estimated that of the 17 waterbird species that nest in three lakes of the Buenos Aires province, 11 were present in Los Padres and in La Brava lakes.

Despite these similarities, the larval digenean assemblages of $H$. parchappii showed different temporal dynamics in La Brava and Los Padres lakes and, also, different correlations with the abiotic and biotic factors analyzed during this study (temperature, high of the water column and snail relative abundance). In La Brava lake, prevalence evidenced temporal heterogeneity and were only positively correlated with the snail relative abundance. In Los Padres lake, prevalence did not show temporal variations or positive correlations with any of the factors analyzed. With respect to species richness, only the digenean assemblage of $H$. parchappii in Los Padres lake evidenced temporal heterogeneity. 
These different dynamics in prevalences and species richness of larval digeneans in the two lakes seem to be related to a series of interacting factors (diversity and abundance of definitive hosts, intermediate and definitive host location, snail relative abundance and anthropogenic disturbances). Regarding to definitive hosts diversity and abundance, during the warmer seasons (spring, summer and early autumn), JosENs et al. $(2009,2012)$ registered the highest species richness and abundance of birds, potential definitive hosts for digeneans, in La Brava and Los Padres lakes. Taking into account that birds are the main contributors to the digenean life cycles in the two lakes ( $75 \%$ of the species registered have birds as definitive hosts of their life cycles), a diverse and abundant fauna of birds can contribute to increase the influx of infective larvae from the definitive host to the snail hosts. Positive correlations between definitive host diversity and parasite diversity in first intermediate hosts have been previously reported by HECHINGER \& LAFFERTY (2005), FREDENSBORG et al. (2006) and BYERs et al. (2010).

The infective larvae released from the definitive host should quickly contact and infect the next host of the life cycle to survive. For this reason, it is essential that upstream and downstream hosts of the digenean life cycle coincide in the same location. In La Brava lake, the snail H. parchappii is located on the giant bulrush, $S$. californicus, in dense stands growing near the shore. In these stands, we observed that the number of bird species feeding and resting is lower compared with other littoral areas of the lake. However, during the warmer months we found there is a higher abundance of snails, which could increase the chances of contact between snails and birds, favoring the transmission and increasing the prevalence of digeneans species transmitted by those birds that normally frequent the stands. In fact, digenean prevalence in La Brava lake showed temporal variation and positive correlation with the snail relative abundance. On the other hand, the density of the stands of S. californicus could hinder the contact of other local and visitor bird species with the population of $H$. parchappii, preventing the seasonal variation in species richness.

In Los Padres lake, $H$. parchappii is located mainly between the shore and the vegetated area of littoral zone and, to a lesser extent, in the stands of S. californicus. This area of the lake is easily accessible for birds and is used, throughout the year, by local bird species to feed and rest and, during the warmer months, is also frequented by transient bird species. This seasonal increase in bird diversity and abundance could explain the temporal variation in species richness of larval digenean assemblages of $H$. parchappii in the lake but not the absence of temporal variation in prevalence.

As mentioned earlier, over the last years, La Brava and Los Padres lakes have been impacted by human disturbances, derived from agricultural and recreational activities, urbanization and waste increase from different origins (Romanelli et al., 2014). Several studies have confirmed the anthropogenic impact on the two lakes, showing the presence of diverse pollutants (heavy metals, pesticides and herbicides) in water, soil, aquatic macrophytes, and fauna (MiglioranZa et al., 1998, 2004; RoMANELLi et al., 2014).
The urbanization of the areas surrounding the lakes has increased markedly in recent years, and the constructed area covers $2.2 \%$ and $6.6 \%$ of the shoreline in La Brava and Los Padres lakes, respectively. In both lakes residential zones have been developed: La Brava village (northern zone of La Brava lake) with approximately 300 residents and Los Padres village with a thousand of families (ROMANELLI et al., 2013). To the presence of permanent residents must be added the presence of visitors during weekends and holidays, a large number of people that use these areas for recreational activities. These recreational activities, that include fishing, picnicking and, in some occasions, forbidden activities like campfires (RomANelli et al., 2013) increase during spring and summer.

In Los Padres lake, the largest numbers of visitors are concentrated in the contact zone between birds and snails. This increase in human presence reduces the number of birds that feed or rest on the shore, limiting the release of infective larvae of digeneans (miracidia) from the definitive hosts. Although the density of snails and the diversity and abundance of birds increase in the warmer months, disturbances due to human activities could prevent a stronger increase in prevalence during those months and, consequently, could prevent the existence of temporal variations in the prevalence of larval digenean assemblages parasitizing $H$. parchappii in Los Padres lake.

In La Brava lake, recreational activities also have their maximum peak in spring and summer, but the visitors rarely frequent the zone of dense stands of $S$. californicus where birds and snails coincide. However, the increase in human presence in La Brava lake could also interfere with the arrival of transient bird species to the stands, and contribute to the absence of temporal variation in species richness registered in the larval digenean assemblage of $H$. parchappii.

Finally, in regards to the occurrence of interspecific competition in the larval digenean assemblages of $H$. parchappii, no multiple infestations were registered in Los Padres lake, while in La Brava lake, multiple infestations represented $2.3 \%$ of total infestations. Some authors considered interspecific competition as an important structuring factor of the larval digenean assemblages (e.g. KURIS \& LAFFERTY, 1994; LAFFERTY et al., 1994). As a result of this competition, subordinate species can be excluded from the assemblages by dominant species and, for this reason, its presence could not be detected in the samples. Due to the fact that a dominance hierarchy in the larval digenean assemblages of $H$. parchappii in the two lakes has not yet been established, it was not possible to apply the methodology suggested by LAFFERTY et al. (1994) to estimate the expected prevalence of digeneans that would have occurred in a sample of snails in the absence of competition. Consequently, based on our results, interspecific competition cannot be totally dismissed as structuring factor of the larval digenean assemblages of H. parchappii, at least, in La Brava lake.

In summary, the temporal dynamics in prevalence and species richness of larval digenean assemblages of $H$. parchappii in La Brava and Los Padres lakes seems to be influenced by a series of factors (diversity and abundance of definitive hosts, intermediate and definitive host location, 
snail relative abundance and anthropogenic disturbances). However, comparatively, the local interaction of these factors determines different temporal patterns of diversity and abundance of larval digeneans. Our results highlight the importance of analyzing the role of the factors that structure larval digenean assemblages at the local level, especially in studies dealing with spatiotemporal fluctuations or with distance decay of similarities in species richness of parasite assemblages.

Acknowledgements. The present study was funded by grants from FONCYT (PICT No. 1974 to M. J. M.) and Universidad Nacional de Mar del Plata (No. 15/E831 EXA873/18 to J. A. E.).

\section{REFERENCES}

Blanar, C. A.; Munkittrick, K. R.; Houlahan, J.; Maclatchy, D. L. \& Marcogliese, D. J. 2009. Pollution and parasitism in aquatic animals: a meta-analysis of effect size. Aquatic Toxicology 93:18-28.

Byers, J. E.; Altman, I.; Grosse, A. M.; Huspeni, T. C. \& Maerz, J. C. 2010. Using parasitic trematode larvae to quantify an elusive vertebrate host. Conservation Biology 25:85-93.

Byers, J. E.; Blakeslee, A. M. H.; Linder, E.; CoOper, A. B. \& Maguire, T. J. 2008. Controls of spatial variation in the prevalence of trematode parasites infecting a marine snail. Ecology 89:439-451.

COMBES, C. 2001. Parasitism. The ecology and evolution of intimate interactions. Chicago, The University of Chicago Press. 552p.

Curtis, L. A. \& Hubbard, K. M. 1990. Trematode infections in a gastropod host misrepresented by observing shed cercarie. Journal of Experimental Marine Biology and Ecology 143:131-137.

Curtis, L. A. \& Hurd, L. E. 1983. Age, sex, and parasites: Spatial heterogeneity in a sandflat population of Ilyanassa obsoleta. Ecology 64:819-828.

Di Giorgio, G.; Gilardoni, C.; Bagnato, E.; Cremonte, F. \& Ituarte, C. 2016. Preference of larval digenean for one of the two sympatric host snails in different stressful habitat from Patagonia, Southwestern Atlantic coast. Journal of Helminthology 91:696-702.

Esch, G. W. \& FernándeZ, J. C. 1994. Snail-trematode interactions and parasite community dynamics in aquatic systems: A review. American Midland Naturalist 131:209-237.

Esch, G. W.; CurTis, L. A. \& BARgER, M. A. 2001. A perspective on the ecology of trematode communities in snails. Parasitology 123:57-75.

Etchegoin, J. A. \& Martorelli, S. R. 1998. Nuevas cercarias en Heleobia conexa (Mollusca: Hydrobiidae) de la albufera Mar Chiquita. Neotrópica 44:41-50.

EtChegorn, J. A. \& MerLo, M. J. 2011. Heleobia conexa y H. australis como boindicadores de fauna y de fluctuaciones ambientales en la laguna Mar Chiquita (Buenos Aires, Argentina). Amici Molluscarum. Número especial:33-35.

Etchegoin, J. A.; Merlo, M. J. \& Parietti, M. 2012. The role of the invasive polychaete Ficopomatus enigmaticus (Fauvel, 1923) (Serpulidae) as facilitator of parasite transmission in Mar Chiquita coastal lagoon (Buenos Aires, Argentina). Parasitology 139:1506-1512.

FaltýnKová, A.; Valtonen, E. T. \& Karvonen, A. 2008. Spatial and temporal structure of the trematode component community in Valvata macrostoma (Gastropoda, Prosobranchia). Parasitology 135:1691-1699.

FERNÁNDEZ, J. \& EsCH, G. W. 1991. Guild structure of larval trematodes in the snail Helisoma anceps: patterns and processes at the individual host level. Journal of Parasitology 77:528-539.

Fingerut, J. T.; Zimmer, C. A. \& Zimmer, R. K. 2003. Patterns and processes of larval emergence in an estuarine parasite system. The Biological Bulletin 205:110-120.

Fredensborg, B .L.; Mouritsen, K. N. \& Poulin, R. 2006. Relating bird host distribution and spatial heterogeneity in trematode infections in an intertidal snail-from small to large scale. Marine Biology 149:275-283.

Galaktionov, K. V. \& DobrovolskiJ, A. A. 2003. The biology and evolution of trematodes: an essay on the biology, morphology, life cycles, transmission, and evolution of digenetic trematodes. Dordrecht, Kluwer Academic Publishers. 592p.

GÉRARD, C. 2001. Structure and temporal variation of trematode and gastropod communities in a freshwater ecosystem. Parasite 8:275-287.

GinetsinskaYa, T. A. 1988. Trematodes, their life cycles, biology and evolution. New Delhi, Amerind Publishing Co. Pvt. Ltd. 559p.

Granovitch, A. I.; Sergievsky, S. O. \& Sokolova, I. M. 2000. Spatial and temporal variation of trematode infection in coexisting populations of intertidal gastropods Littorina saxatilis and L. obtusata in the White Sea. Diseases of Aquatic Organisms 41:53-64.

HeChingER, R. F. \& LAFFERTY, K. D. 2005. Host diversity begets parasite diversity: bird final hosts and trematodes in snail intermediate hosts. Proceedings of the Royal Society B: Biological Sciences 272:10591066.

Herrmann, K. K. \& Sorensen, R. E. 2009. Seasonal dynamics of two mortality-related trematodes using an introduced snail. Journal of Parasitology 95:823-828.

HusPeni, T. C. \& LAFFERTY, K. D. 2004. Using larval trematodes that parasitize snails to evaluate a saltmarsh restoration project. Ecological Application 14:795-804.

JoKela, J. \& Lively, C. M. 1995. Spatial variation in infection by digenetic trematodes in a population of freshwater snails (Potamopyrgus antipodarum). Oecologia 103:509-517.

Josens, M. L.; EsCALANTE, A. H. \& Favero, M. 2012. Diversity, seasonality and structure of bird assemblages associated with three wetlands in the Southeastern Pampas, Argentina. Ardeola 59:93-109.

Josens, M. L.; Pretelli, M. G. \& Escalante, A. H. 2009. Censos de aves acuáticas en sus colonias reproductivas en lagunas del sudeste de la Provincia de Buenos Aires. Hornero 24:7-12.

Keas, B. E. \& Blankespoor, H. D. 1997. The prevalence of cercariae from Stagnicola emarginata (Lymnaeidae) over 50 years in Northern Michigan. Journal of Parasitology 83:536-540.

Kube, J.; Kube, S. \& DiesChKe, V. 2002. Spatial and temporal variations in the trematode component community of the mudsnail Hydrobia ventrosa in relation to the occurrence of waterfowl as definitive hosts. Journal of Parasitology 88:1075-1086.

Kuris, A. M. \& LAFFERTY, K. D. 1994. Community structure: larval trematodes in snail host. Annual Review of Ecology and Systematics 25:189-217.

LAFFERTY, K. D. 1997. Enviromental parasitology: what can parasites tell us about human impacts on the enviroment? Parasitology Today 3:251-255.

LAFFERTY, K. D.; SAMmond, D. T. \& KuRIS, A. M. 1994. Analysis of larval trematode communities. Ecology 75:2275-2285.

Ludwig, J. A. \& ReYnolds, J. F. 1988. Statistical Ecology. New York, John Wiley and Sons Inc. 337p.

MagurRan, A. E. 1988. Ecological diversity and its measurement. Princeton, Princeton University Press. 192p

Martín, P. R.; Estebenet, A. L. \& CAZZANiga, N. J. 2001. Factors affecting the distribution of Pomacea canaliculata (Gastropoda: Ampullariidae) along its southernmost natural limit. Malacologia 43:13-23.

Martorelli, S. R. 1986. Estudio sistemático y biológico de un digeneo perteneciente a la familia Microphallidae Travassos, 1920. II: desarrollo del ciclo biológico de Microphallus szidati en dos ambientes de condiciones ecológicas diferentes. Revista Iberoamericana de Parasitología 46:379-385.

Martorelli, S. R. 1989. Estudios parasitológicos en biotopos lénticos de la República Argentina. V. Desarrollo del ciclo biológico monoxeno de la metacercaria progenética de Genarchella genarchella Travassos, 1928 (Digenea, Hemiuridae) parasita de Littoridina parchappei (Mollusca, Hidrobiidae). Revista del Museo de La Plata 14:109-117.

Martorelli, S. R. 1990. Estudios parasitológicos en la albufera de Mar Chiquita, provincia de Buenos Aires, República Argentina.III: sobre dos cercarias parasitas de Heleobia conexa (Mollusca: Hydrobiidae) pertenecientes a la superfamilia Echinostomatoidea. Neotrópica 36:512.

Martorelli, S. R. \& Etchegoin, J. A. 1996. Cercarias de la superfamilia Opisthorchioidae en Heleobia conexa (Mollusca: Hydrobiidae) de la albufera de Mar Chiquita. Neotrópica 42:61-68.

Merlo, M. J.; Parietti, M. \& Etchegoin, J. A. 2010. Evaluation of species richness estimators in studies of diversity involving two larval 
digenean communities parasitizing snail hosts. Parasitology Research 107:1093-1102.

Merlo, M. J.; Parietti, M. \& Etchegoin, J. A. 2014. Digeneos larvales de Heleobia parchappii y de Heleobia australis en ambientes dulceacuícolas y estuariales de la provincia de Buenos Aires (Argentina). Revista Argentina de Parasitología 2:14-21.

Miglioranza, K. S. B.; Aizpún de Moreno, J. E. \& Moreno, V. J. 2004. Organochlorine pesticidas sequestered in the aquatic macrophyte Schoenoplectus californicus from a shallow lake in Argentina. Water Research 38:1765-1772.

Miglioranza, K. S. B.; Aizpún de Moreno, J. E.; Moreno, V. J.; Osterrieth, M. \& Escalante, A. H. 1998. Fate of organochlorine pesticides in soils and terrestrial biota of Los Padres pond watershed, Argentina. Environmental Pollution 100:1-9

Parietti, M.; Merlo, M. J. \& Etchegoin, J. A. 2013. Can the studies at a spatial scale of 100 s meters detect the spatiotemporal fluctuations of a parasite assemblage? Acta Parasitologica 58:577-584.

Pietrock, M. \& Marcogliese, D. J. 2003. Free-living endohelminth stages: at the mercy of environmental conditions. Trends in Parasitology 19:293-299.

Poulin, R. 2006. Global warming and temperature-mediated increases in cercarial emergence in trematode parasites. Parasitology 132:143-151.

Poulin, R. \& Mouritsen, K. N. 2006. Climate change, parasitism and the structure of intertidal ecosystems. Journal of Helminthology 80:183-191.

Romanelli, A.; Esquius, K. S.; Massone, H. E. \& Escalante, A. H. 2013. GIS-based pollution hazard mapping and assessment framework of shallow lakes: southeastern Pampean lakes (Argentina) as a case study. Environmental Monitoring and Assessment 185:6943-6961.

Romanelli, A.; Lima, M. L.; Massone, H. E. \& Esquius, K. S. 2014. Spatial decision support system for assessing lake pollution hazard: southeastern pampean shallow lakes (Argentina) as a case study. Wetlands Ecology and Management 22:247-265. DOI: 10.1007/s11273-013-9327-1

Romanelli, A.; Massone, H. E. \& Qutrozl, O. M. 2011. Integrated Hydrogeological Study of Surface \& Ground Water Resources in the Southeastern Buenos Aires Province, Argentina. International Journal of Environmental Research 5:1053-1064. DOI: 10.22059/ IJER.2011.463

Rumi, A.; Gutiérrez Gregoric, D. E.; NúÑez, V. \& Darrigan, G. A. 2008. Malacología Latinoamericana. Moluscos de agua dulce de Argentina. Revista de Biología Tropical 56:77-111.

Skirnisson, K.; Galaktionov, K. V. \& Kozminsky, E. V. 2004. Factors influencing the distribution of digenetic trematode infections in a mudsnail (Hydrobia ventrosa) population inhabiting salt marsh ponds in Iceland. Journal of Parasitology 90:50-59.

SouSA, W. P. 1993. Interspecific antagonism and species coexistence in a diverse guild of larval trematode parasites. Ecological Monographs 63:103-128.

Studer, A. \& Poulin, R. 2012. Seasonal dynamics in an intertidal mudflat: the case of a complex trematode life cycle. Marine Ecology Progress Series 455:79-93.

Sukhdeo, M. V. K. \& Sukhdeo, S. C. 2004. Trematode behaviours and the perceptual worlds of parasites. Canadian Journal of Zoology 82:292-315.

SzIDAT, L. 1956. Uber den entwicklungszyklus mit progenetischen Larvenstadien (Cercariaeen) von Genarchella genearchella Travassos, 1928 (Trematoda, Hemiuridae) und die Moglichkeit einer hormonalen Beeinflussung der Parasiten durch ihre Wirtstiere. Zeitschrift für Tropenmedizin und Parasitologie 7:132-153.

YAmaguti, S. 1975. A synoptical review of life histories of digenetic trematodes of vertebrates: With special reference to the morphology of their larval forms. Tokyo, Keigaku Publishing Co. 590p.

Yurlova, N. I.; Vodyanitskaya, S. N.; Serbina, E. A.; Biserkov, V. Y.; Georgiev, B. B. \& Chipev, N. H. 2006. Temporal variation in prevalence and abundance of metacercariae in the pulmonate snail Lymnaea stagnalis in Chany Lake, West Siberia, Russia: long-term patterns and environmental covariates. Journal of Parasitology 92:249-259.

ZAR, J. H. 2009. Biostatistical Analysis. New Jersey, Pearson Education Inc. $944 p$. 